\title{
Multiple intestinal haemangiomas presenting as intussusception and bleeding
}

\author{
Khalil EIGendy, Amro Salem
}

Department of Colorectal Surgery, King Fahad Specialist Hospital, Dammam, Eastern Province, Saudi Arabia

\section{Correspondence to}

Dr Khalil ElGendy,

k.m.elgendy@gmail.com

Accepted 8 September 2014

\section{DESCRIPTION}

A 17-year-old girl was referred to the colorectal surgery unit with a history of multiple hospital admissions due to recurrent abdominal pain, lower gastrointestinal (GI) bleeding and severe anaemia with haemoglobin reaching a low of $3 \mathrm{~g} / \mathrm{dL}$ in one episode. Clinical examination was unremarkable. Colonoscopy revealed two lesions suggestive of haemangiomas at the rectosigmoid region and at the hepatic flexure (figure 1). Nuclear medicine GI bleeding scintigraphic scanning revealed active bleeding from the hepatic flexure. The patient was admitted due to an acute episode of intestinal obstruction and bleeding per rectum. CT angiogram (figure 2) revealed intussusception at the small bowel with characteristic findings in the form of a sausage-shaped mass with visible layers in the coronal (A) and axial (B) views and target sign in

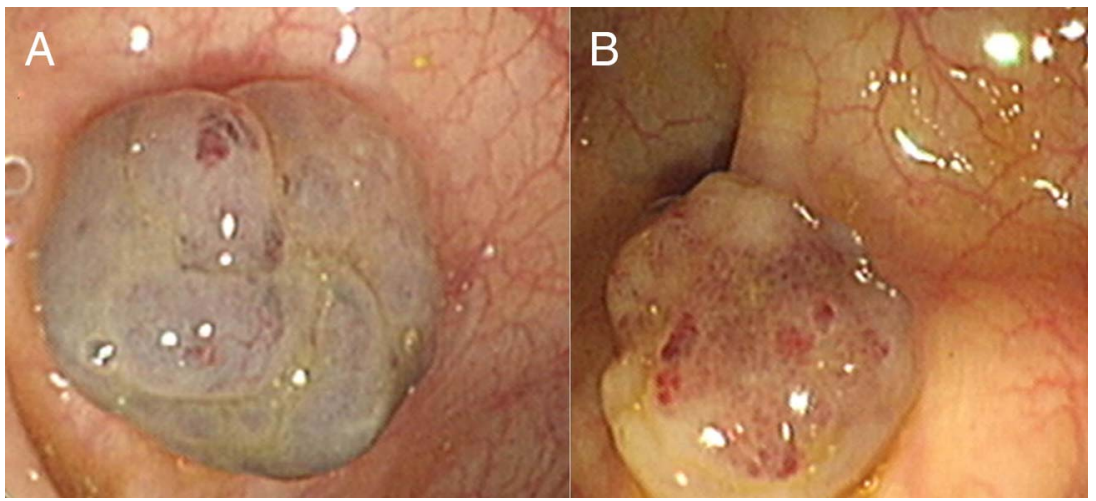

Figure 1 Colonoscopy revealing haemangiomas at (A) rectosigmoid and (B) hepatic flexure.

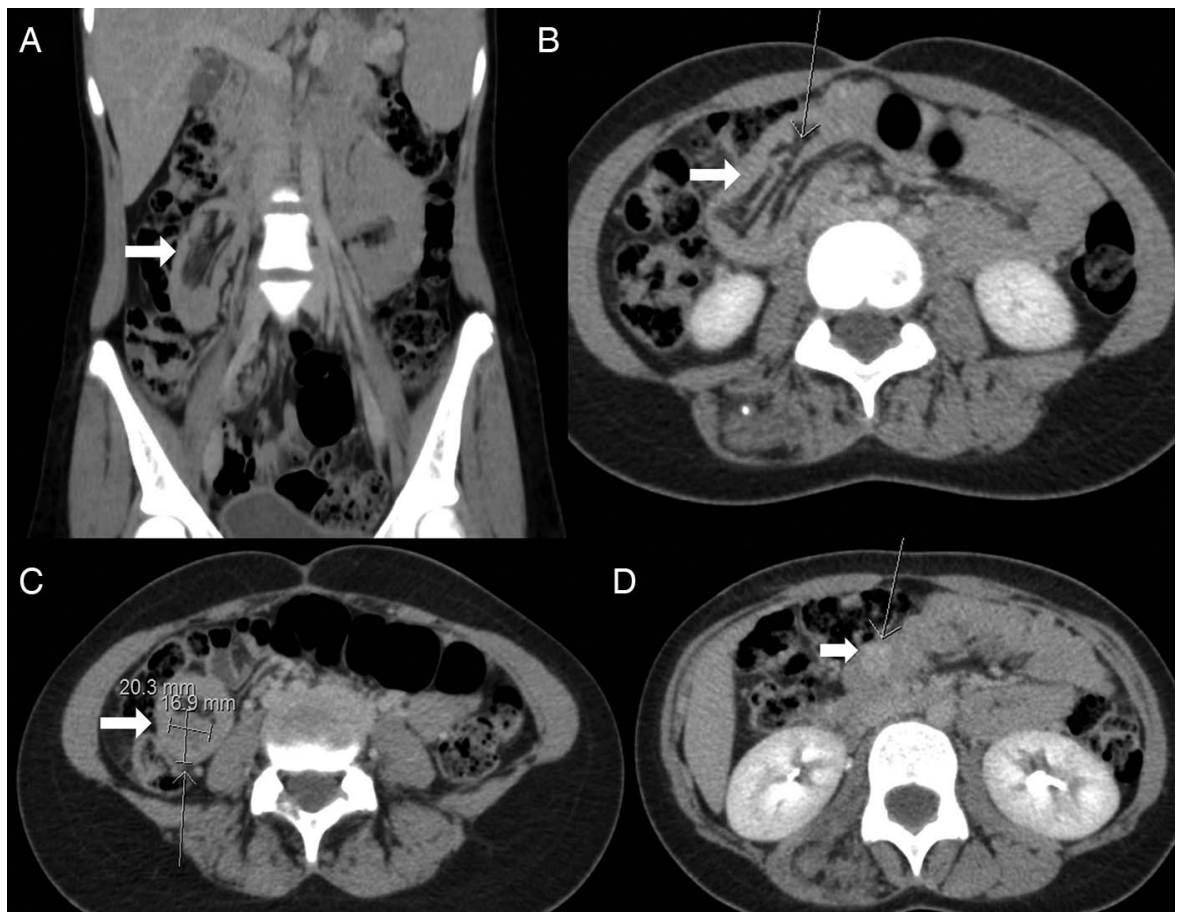

To cite: ElGendy K, Salem A. BMJ Case Rep Published online: [please include Day Month Year] doi:10.1136/bcr-2014206365 


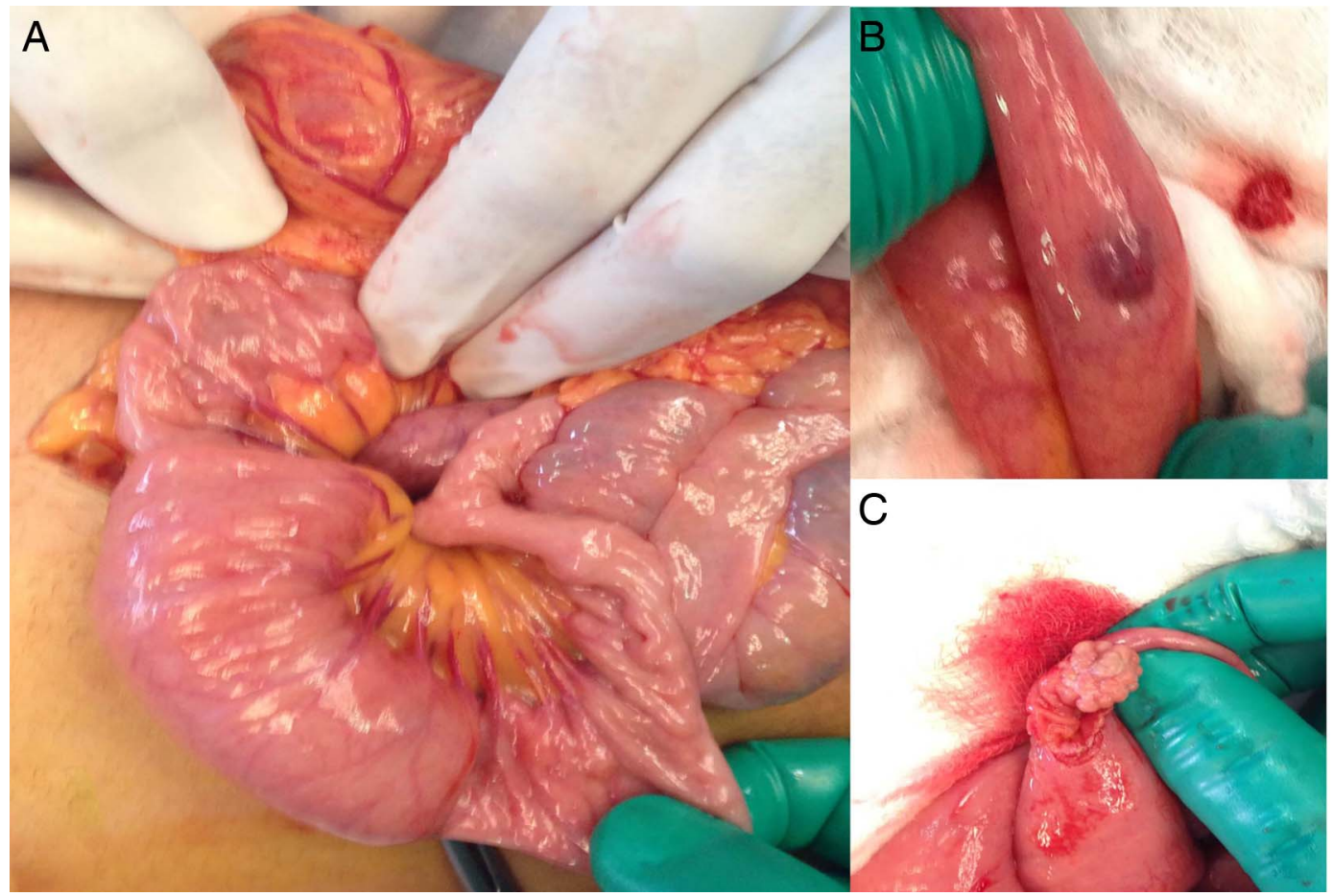

Figure 3 Intraoperative findings of intussusception (A), and haemangioma after resection of the intussusception (B) and after enterotomy (C).

another axial view (C) associated with haemangioma as the leading point (size $20.3 \mathrm{~mm} \times 16.9 \mathrm{~mm}$ ). In addition, another haemangioma was identified (figure 2D) with no findings suggestive of the active bleeding site.

Surgical exploration was offered and revealed the intussusception, with identification of the haemangioma as the leading point after the reduction (figure 3). Enterotomy was performed and revealed multiple haemangiomas close to the intussusception site, present over a segment of $20 \mathrm{~cm}$, requiring small bowel resection of that segment and primary anastomosis. Colotomy, ligation and excision were done over the preidentified haemangiomas in the hepatic flexure and rectosigmoid region. The pathological examination was reported to be multiple cavernous haemangioma. The patient had a smooth postoperative recovery with follow-up to 1 year without any attacks of abdominal pain or bleeding.

\section{Learning points}

- Multiple intestinal haemangiomas are very rare disorders and can present with bleeding and intussusception.

- A variety of investigations are required to diagnose such cases, which might include CT, MRI, scintigraphic scanning and endoscopy including capsule one.

- Surgery can be offered in selective cases with appropriate preoperative work up and diagnosis.
Multiple intestinal haemangiomas are a very rare disorder. Adult intussusceptions are mostly caused by leading lesions, with very few cases caused by haemangiomas. ${ }^{1}$ Colonic involvement is uncommon, with solitary lesions usually involving the rectosigmoid. ${ }^{2}$ However, there is no reported case of multiple intestinal haemangiomas involving both the small and large bowel with a presentation of intussusception. Such cases are challenging and need comprehensive and extensive investigation to reach the diagnosis, find the extent of the disease and bleeding site, and prepare a subsequent management plan. ${ }^{3}$ Investigations may include: CT angiogram, scintigraphic studies and capsule endoscopy. MRI proved to be more accurate in demonstrating the extension of the lesions in selective cases. ${ }^{4}$

Contributors KE was involved in case scenario, literature review and manuscript preparation; AS was involved in management of the case, informed consent and final revision.

Competing interests None.

Patient consent Obtained.

Provenance and peer review Not commissioned; externally peer reviewed.

\section{REFERENCES}

1 Kim SY, Jeon TJ, Hong JH, et al. An adult case of small bowel intussusception caused by hemangioma presenting with intestinal bleeding. Korean J Gastroenterol 2008;52:183-7.

2 Gesslein M, Koscheck T, Kusch B. Capillary hemangioma of the colon as a rare cause of intussusception in adults. Dtsch Med Wochenschr 2004;129:1970-2.

3 Amarapurkar D, Jadliwala M, Punamiya $S$, et al. Cavernous hemangiomas of the rectum: report of three cases. Am J Gastroentero/1998;93:1357-9.

4 Kandpal H, Sharma R, Srivastava DN, et al. Diffuse cavernous haemangioma of colon: magnetic resonance imaging features. Report of two cases. Australas Radiol 2007;51:147-51. Spec No.:B147-51.. 
Copyright 2014 BMJ Publishing Group. All rights reserved. For permission to reuse any of this content visit http://group.bmj.com/group/rights-licensing/permissions.

BMJ Case Report Fellows may re-use this article for personal use and teaching without any further permission.

Become a Fellow of BMJ Case Reports today and you can:

- Submit as many cases as you like

- Enjoy fast sympathetic peer review and rapid publication of accepted articles

- Access all the published articles

- Re-use any of the published material for personal use and teaching without further permission

For information on Institutional Fellowships contact consortiasales@bmjgroup.com

Visit casereports.bmj.com for more articles like this and to become a Fellow 